\title{
Ketogenic diet does not affect strength performance in elite artistic gymnasts
}

\author{
Antonio Paoli ${ }^{1} 2^{*}$, Keith Grimaldi ${ }^{3}$, Dominic D'Agostino ${ }^{4}$, Lorenzo Cenci ${ }^{5}$, Tatiana Moro ${ }^{1}$, Antonino Bianco ${ }^{6}$ \\ and Antonio Palma ${ }^{6}$
}

\begin{abstract}
Background: Despite the increasing use of very low carbohydrate ketogenic diets (VLCKD) in weight control and management of the metabolic syndrome there is a paucity of research about effects of VLCKD on sport performance. Ketogenic diets may be useful in sports that include weight class divisions and the aim of our study was to investigate the influence of VLCKD on explosive strength performance.
\end{abstract}

Methods: 8 athletes, elite artistic gymnasts (age 20.9 $\pm 5.5 \mathrm{yrs}$ ) were recruited. We analyzed body composition and various performance aspects (hanging straight leg raise, ground push up, parallel bar dips, pull up, squat jump, countermovement jump, 30 sec continuous jumps) before and after 30 days of a modified ketogenic diet. The diet was based on green vegetables, olive oil, fish and meat plus dishes composed of high quality protein and virtually zero carbohydrates, but which mimicked their taste, with the addition of some herbal extracts. During the VLCKD the athletes performed the normal training program. After three months the same protocol, tests were performed before and after 30 days of the athletes' usual diet (a typically western diet, WD). A one-way Anova for repeated measurements was used.

Results: No significant differences were detected between VLCKD and WD in all strength tests. Significant differences were found in body weight and body composition: after VLCKD there was a decrease in body weight (from $69.6 \pm 7.3 \mathrm{Kg}$ to $68.0 \pm 7.5 \mathrm{Kg}$ ) and fat mass (from $5.3 \pm 1.3 \mathrm{Kg}$ to $3.4 \pm 0.8 \mathrm{Kg} \mathrm{p}<0.001$ ) with a non-significant increase in muscle mass.

Conclusions: Despite concerns of coaches and doctors about the possible detrimental effects of low carbohydrate diets on athletic performance and the well known importance of carbohydrates there are no data about VLCKD and strength performance. The undeniable and sudden effect of VLCKD on fat loss may be useful for those athletes who compete in sports based on weight class. We have demonstrated that using VLCKD for a relatively short time period (i.e. 30 days) can decrease body weight and body fat without negative effects on strength performance in high level athletes.

Keywords: Very low carbohydrate Ketogenic diet, Body composition, Weight loss, Strength, Gymnastic

\section{Background}

Many procedures used for body weight reduction by athletes in sports that include weight categories lead to a series of negative side effects which directly influence physiological efficiency during sports performance. The practice of rapidly losing a significant amount of weight,

\footnotetext{
* Correspondence: antonio.paoli@unipd.it

'Physiological Laboratory - Department of Biomedical Sciences, University of Padova, Padova, Italy

${ }^{2}$ Human Movement Sciences School, University of Padova, Padova, Italy

Full list of author information is available at the end of the article
}

through low calorie diets, deliberate dehydration, saunas etc., just before competition, is widespread [1-3]. These traditional methods are often unsafe and typically impair health, physiological function, water balance, electrolytes, glycogen and lean body mass [1,4-6] and are sometimes illegal as with the use of diuretics [3].

However for athletes competing in sports divided into weight categories a safe method of weight loss that does not impair performance can be a legitimate and important tool. For example, bodybuilders regularly need to reduce fat and/or weight before competition preferably

\section{Ciomed Central}


without affecting muscle strength or muscle size [7] and a VLCKD (very low carbohydrate ketogenic diet) is commonly used to achieve this. VLCKD is a diet in which the daily carbohydrate intake is below $30 \mathrm{~g}$ and this restriction limits glucose availability to tissues, stimulating ketogenesis in the liver. The physiological function of ketosis is to supply the heart and central nervous system (CNS) with a high energy metabolic substrate during reduced glucose availability - by this mechanism ketones allowed our ancestors to survive and remain efficient even when deprived of food [8,9]. On this basis the ketosis induced by a VLCKD may be defined as "physiological ketosis" to distinguish it from the severe pathological ketosis (or ketoacidosis) commonly seen in uncontrolled diabetes [10-12]. The use of low carbohydrate ketogenic diets for weight loss, despite their efficacy, has been an area of controversy. In the last few years though an increasing amount of evidence has accumulated concerning the positive effects on short term weight loss, metabolic profile with regards to insulin sensitivity, glycemic control and serum lipid values [12-16]. These effects appear potentially very attractive for athletes needing to lose fat mass quickly but, curiously, despite the huge amount of scientific literature about ketogenic diets, their influence on sport performance remains poorly investigated. Recently Kreider and colleagues studied the effect of a specific exercise program in overweight woman with a VLCKD or normal carbohydrate content diet [17], but only few papers that focus specifically on the influence of VLCKD on sports performance have been published, and with conflicting results: showing benefits $[18,19]$, no effect $[20,21]$ or impairment $[22,23]$.

The present study set out to investigate if a VLCKD could be useful for athletes, especially for those engaged in sports involving weight categories where weight loss without negative changes in the body composition (i.e. loss of muscle mass) and performance is often needed. To the best of our knowledge no previous study has investigated the influence of a VLCKD on strength performance and on explosive strength performance in competitive athletes.

\section{Methods}

\section{Subjects}

Nine high-level male athletes (age $21 \pm 5.5$ ), elite artistic gymnasts, were recruited for this study. Subjects competed in the Italian premier league for the CorpoLibero Gymnastics Team ASD, Padova, Italy and include two athletes belonging to the Italian national team. The mean volume of weekly training was about 30 hours. During the VLCKD period (30 days) the athletes were asked to keep to their normal training schedule. During a preliminary meeting it was explained that during the first three weeks it was necessary to almost totally exclude carbohydrates and a detailed menu containing permitted and nonpermitted foods was provided to each participant, along with the components of the ketogenic diet with phytoextracts diet described below. All gymnasts read and signed an informed consent with the testing procedures approved by the council of the Human Anatomy and Physiology Department, University of Padova.

\section{Experimental design}

Subject measurements were taken, according to the methodology described below, before starting the VLCKD and repeated after thirty days of VLCKD. Since we chose a within subject design to strengthen the study (Subjects served as their own control), the athletes were re-tested during a second training period comparable in terms of intensity and volume of training to the first one.. The work load between athletes was similar because the team training regimes are strictly controlled, and recorded, due to the elite nature of their competition. The protocol took place three months later to ensure a comparable training load and achieve this goal the intensity and volume of training during the two periods (hours of training, kind of exercises, etc.) was

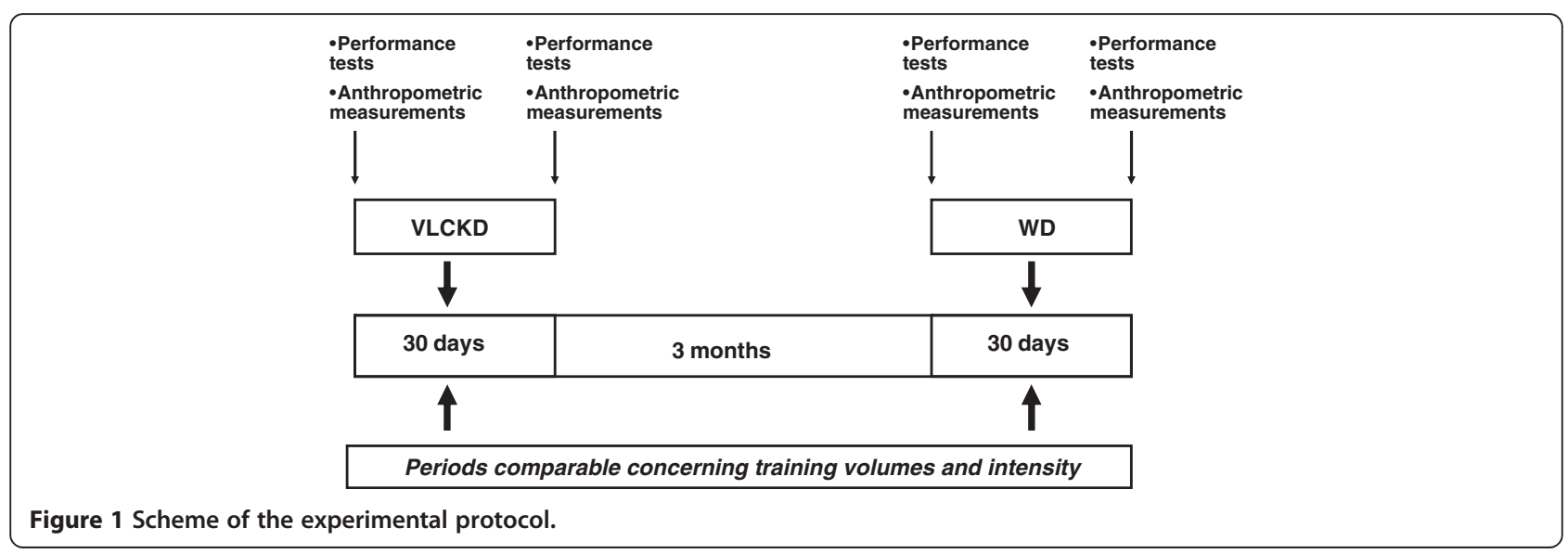


carefully measured. During the second experimental session the subjects followed their normal diet (WD) instead of the VLCKD. The test procedure before and after WD was the same as the first testing session (Figure 1). As in the experimental period also during the control period the athletes were invited to continue their normal training. One subject withdrew from the study due to injury.

\section{Diet}

Before the start of the study, each athlete was given a detailed list containing the foods permitted and prohibited in a ketogenic diet. The diet consumed was primarily made of beef and veal, poultry, fish, raw and cooked green vegetables without restriction, cold cuts (dried beef, carpaccio and cured ham), eggs and seasoned cheese (e.g. parmesan). The drinks allowed were infusion tea, moka coffee and the herbal extracts. The foods and drinks that athletes avoided included alcohol, bread, pasta, rice, milk, yogurt, soluble tea and barley coffee. In addition to facilitate the adhesion to the nutritional regime, each athlete was given a variety of speciality meals constituted principally of protein and fiber These meals (TISANOREICA ${ }^{\circledR}$ by Gianluca Mech SpA, Asigliano Veneto, Vicenza, Italy) which are composed of high quality protein (equivalent to 18 grams/portion) and virtually zero carbohydrate (but that mimic their taste) were included in the standard ration $[16,24]$.

Both the foods mentioned in the list and the standard ration could be consumed during the same meal and VLCKD was taken by athletes ad libitum. During the VLCK diet, the athletes also consumed some specific herbal extracts: $20 \mathrm{ml}$ of extract A, $20 \mathrm{ml}$ of extract B and $50 \mathrm{ml}$ of extract $\mathrm{C}$ as described in Tables 1 and 2 . Moreover, during ketogenic diet periods, athletes assumed 1 caplet in of a multivitamin-mineral supplement each morning $([19,25,26]$. The composition of the caplets was: Magnesium19 mg, Calcium $16 \mathrm{mg}$, Phosphorus $8 \mathrm{mg}$, Zinc $4.5 \mathrm{mg}$, Iron $4.62 \mathrm{mg}$, Manganese $1 \mathrm{mg}$, Potassium $0.5 \mathrm{mg}$, Copper $0.4 \mathrm{mg}$, Chromium $28.55 \mu \mathrm{g}$, Selenium $4 \mu \mathrm{g}$, Niacin $10 \mathrm{mg}$, Beta carotene
$1.8 \mathrm{mg}$, Folic Acid $66 \mu \mathrm{g}$, Biotin $30 \mu \mathrm{g}$, Vitamin C $19.8 \mathrm{mg}$, Vitamin E $3.3 \mathrm{mg}$, Pantothenic Acid $1.98 \mathrm{mg}$, Vitamin B6 $0.66 \mathrm{mg}$, Vitamin B2 $0.53 \mathrm{mg}$, Vitamin B1 $0.426 \mathrm{mg}$, Vitamin D3 $1.65 \mu \mathrm{g}$, Vitamin B12 $0.33 \mu \mathrm{g}$ (Multivitaminico Balestra e Mech, Gianluca Mech SpA, Asigliano Veneto VI).

During the second period of the study, the athletes themselves assumed the function of a control group and consumed their usual diet that is very close to the present US diet western diet (WD) [38] with the exception of fat origin (monounsaturated fats, i.e. olive oil in our subjects vs. saturated fats in the typical US diet). The diet consumed was composed mainly of potatoes, whole grains (bread, pasta, whole wheat, rice, and potatoes), meat, fish, eggs, poultry, vegetables, legumes, fruits, condiments (mainly olive oil), whole milk and wine. As with the ketogenic diet, the WD was taken ad libitum according to the nutritional habits of the athletes.

The diets were explained to all subjects by a qualified dietician during an individual visit. Dietary intake was measured by validated 3- day food diary [39] that has been used in the past in studies with athletes [40] and analysed by Dietnext ${ }^{\circledR}$ (Caldogno, Vicenza, Italy) software. During the ketogenic period the prescribed daily intake of carbohydrate was $22 \mathrm{~g}$. The percentage distribution of total daily energy macronutrients was $54.8 \%$ fat, $40.7 \%$ protein and $4.5 \%$ carbohydrates. The total amount of daily kilojoules was $8254.5 \pm 1136$. During the WD period the macronutrients were distributed in the following order: $46.8 \%$ carbohydrate, $38.5 \%$ lipids, $14.7 \%$ protein. The Western diet provided a total daily $\mathrm{kJ}$ $9520.7 \pm 1080.71$ (Table 3).

\section{Measurements}

Before and after the diet period, muscle and fat amounts and percentages, were assessed by skinfold measurement which are highly related to percent body fat in fit and healthy young men [41-43]. We used software (Fitnext ${ }^{\circledR}$, Caldogno, Vicenza, Italy) that includes 9 skinfolds (triceps, biceps, pectoral, subarmpit, subscapular, iliac crest, mid-abdominal, anterior thigh, medial calf), 6 bone

Table 1 Plant extracts used during the VLCKD

\begin{tabular}{lll}
\hline Plant extracts & 20 & Composition \\
\hline Extracts A, ml/day & $\begin{array}{l}\text { Durvillea antarctica, black radish, mint, liquorice, } \\
\text { artichoke, horsetail, burdock, dandelion, rhubarb, gentian, } \\
\text { lemon balm, chinaroot, juniper, spear grass, elder, fucus, anise, } \\
\text { parsley, bearberry, horehound } \\
\text { Extracts B, ml/day }\end{array}$ & $\begin{array}{l}\text { Serenoa, Red clover, Chervil, Bean, Elder, Dandelion, Uncaria, } \\
\text { Equisetum, Horehound, Rosemary }\end{array}$ \\
Extracts C, ml/day & 20 & $\begin{array}{l}\text { Horsetail, asparagus, birch, cypress, couch grass, corn, dandelion, } \\
\text { grape, fennel, elder, rosehip, anise } \\
\text { Extracts D, ml/day (only weeks } 1 \text { and 2) }\end{array}$ \\
& 40 & $\begin{array}{l}\text { Eleuthero, eurycoma longifolia, ginseng, corn, miura puama, } \\
\text { grape, guaranà, arabic coffee, ginger }\end{array}$ \\
\hline
\end{tabular}


Table 2 Main actives ingredients of phytoextracts and their reported beneficial effects

\begin{tabular}{|c|c|c|c|}
\hline Extract & Main Active ingredients & Reported beneficial effects & Refs \\
\hline \multirow[t]{3}{*}{ A } & Mint & - indigestion & [27] \\
\hline & black radish & - antioxidant & \\
\hline & burdock & - choleretic, increases bile secretion helping digestion & [28] \\
\hline \multirow[t]{2}{*}{ B } & $\begin{array}{l}\text { Serenoa Repens (saw } \\
\text { palmetto) }\end{array}$ & hormonal regulating effects & [29] \\
\hline & White bean & $\begin{array}{l}\text { alpha-amylase inhibitory properties and has been } \\
\text { reported to aid weight loss and glycemic control }\end{array}$ & [30] \\
\hline \multirow[t]{3}{*}{ C } & Equisetum & Antioxidant & [32] \\
\hline & Dandelion (Taraxacum & diuretic & [33] \\
\hline & & glycemic control & [34] \\
\hline \multirow[t]{3}{*}{ D } & Ginseng & \multirow{3}{*}{$\begin{array}{l}\text { Ameliorate the commonly reported symptoms of } \\
\text { weakness and tiredness during the } 1^{\text {st }} \text { phase of ketosis ( } 1 / 2 \text { weeks) }\end{array}$} & [35] \\
\hline & Miura Puama & & [36] \\
\hline & Guaranà & & [37] \\
\hline
\end{tabular}

circumferences (arm, forearm, waist, hip, thigh, calf), 4 bone diameters (elbow, wrist, knee, ankle), waistline and hip circumference measurement $[24,44])$. Anthropometric measurements were performed according to the Anthropometric Standardization Reference Manual [45]. Weight was measured to the nearest $0.1 \mathrm{~kg}$ using an electronic scale (Tanita BWB-800 Medical Scales, USA), and height to the nearest $1 \mathrm{~cm}$ using a Harpenden portable stadiometer (Holtain Ltd, UK). Skinfolds were measured to the nearest $1 \mathrm{~mm}$ using a Holtain caliper (Holtain Ltd, UK), and circumferences to the nearest $0.001 \mathrm{~m}$ using an anthropometric tape. All measurements were taken by the same operator (LC) before and during the study according to standard procedures $[45,46]$.

Following the anthropometric assessment a standardized warm-up lasting 15 minutes consisting of callisthenic exercise was carried out. After 5-8 minutes all the athletes underwent the following strength tests:

Table 3 Average macronutrient and total energy intake during the ketogenic and the free diet period

\begin{tabular}{lcc}
\hline & VLCKD & WD \\
\hline CHO g & $22 \pm 2.3$ & $266.1 \pm 30.8$ \\
PRO g & $200.8 \pm 18.3$ & $83.5 \pm 9$ \\
FAT g & $120.2 \pm 29.5$ & $97.3 \pm 14.4$ \\
CHO KJ & $368.5 \pm 38.4$ & $4455.6 \pm 515$ \\
PRO KJ & $3363 \pm 306.5$ & $1398.5 \pm 150.1$ \\
FAT KJ & $4523 \pm 1112.8$ & $3666.6 \pm 543.8$ \\
CHO \% KJ tot & $4.5 \pm 0.5$ & $46.8 \pm 2.1$ \\
PRO \% KJ tot & $40.7 \pm 5.7$ & $14.7 \pm 1.1$ \\
FAT \% KJ tot & $54.8 \pm 6.0$ & $38.5 \pm 2.6$ \\
KJ Tot & $8254.5 \pm 1136.0$ & $9520.7 \pm 1080.7$ \\
\hline
\end{tabular}

Data are expressed as mean and SD. squat jump (SJ), counter movement jump (CMJ), 15 seconds of consecutive CMJs, push-ups test, reverse grip chins test, legs closed barrier maximum test, parallel bar dips test. Jump tests were performed on a contact mat (Ergojump-Bosco system, srl, S. Rufina di Cittaducale, Rieti, Italia), that allowed the measurement of height of jump, time of flight and time of contact. The height of jumps was calculated according to the Asmussen and Bonde-Petersen formula [47]. All jump test techniques assume that the athlete's position on the mat is the same both at take-off and landing. During jumps athlete's hands were kept on hips to minimize upper limbs contribution and trunk was maintained erect. The SJ test was performed from the seated position maintained at least for 1 second (knee secured at $90^{\circ}$ of knee flexion) then athletes were asked to jump. The CMJ starting from a standing position, then subjects were instructed to perform a rapid downward movement to about $90^{\circ}$ of knee flexion immediately followed by an upward movement. The CMJs were consecutively repeated during 15 seconds without recovery between jumps. For CMJs mean jump height and mechanical power per kilogram of body weight were computed [48]. For all three test types the subjects were requested to jump as high as possible. SJ and CMJ were performed three times with two minutes rest between each trial. The best performance was retained and included in the test [49]. The exercises for the upper part of the body were carried out by each athlete until exhaustion. In the push-up test the subjects were positioned with the palms of the hands in support on the floor at shoulder width; at the start of the exercise, the subjects folded their arms while contemporaneously lowering the trunk to the floor.

In the reverse grip chins test the athletes grabbed the bar (as used in artistic gymnastics) at shoulder width; the subjects first brought the chest to the bar height. In 
the legs closed barrier maximum test, the subjects grab the bar and without oscillating the pelvis elevated the lower limbs to bring the back of both feet in contact with the bar. During parallel bar dips test the subjects lowered themselves to the limit allowed by the shoulder joint.

Test-retest reliability for all exercises obtained in our setting was consistent with previous findings: ICCr: SJ O.97, CMJ 0.99, push-up 0.98, reverse grip chins 0.96, leg closed barrier 0.90, parallel dips 0.95 [50-55].

\section{Statical analysis}

A one-way Anova for repeated measurements was used with significance placed at $\mathrm{p}<0.05$. When appropriate a Bonferroni post hoc test was used to compare selected data.

\section{Results}

No significant differences in anthropometric variables or in athletic performance were detected at basal conditions before either experimental trial. There was a significant difference pre and post VLCKD in body weight (from $69.6 \pm 7.3 \mathrm{Kg}$ to $68.0 \pm 7.5 \mathrm{Kg} \mathrm{p}<0.05$ ) (Figure $2 \mathrm{a}$ ), fat mass (from $5.3 \pm 1.3 \mathrm{Kg}$ to $3.4 \pm 0.8 \mathrm{Kg} \mathrm{p}<0.001$ ) (Figure 2b), fat percentage (pre $7.6 \pm 1.4$; post $5.0 \pm 0.9$; $\mathrm{P}<0.001$ ) and lean body mass percentage (from $92.4 \pm 1.44$ to $95.0 \pm 1.0 ; \mathrm{P}<0.001)$ whilst there was no significant difference comparing pre and post WD. Moreover after VLCKD muscle mass (pre $37.6 \mathrm{Kg} \pm 3.9$; post $37.9 \mathrm{Kg} \pm 4.5$ ) and lean body mass (pre $64.2 \pm 6.5$; post $64.6 \pm 7.1$ ) remained substantially constant (Table 4 ).

As can be seen in Table 4 there were no significant differences in any performance tests before and after VLCKD nor before and after WD.

\section{Discussion}

The aim of our research was to verify the effects of a VLCKD on power strength performance in elite athletes. It is well known that VLCKD's promote weight loss very rapidly [56]. Surprisingly, despite the various unhealthy
Table 4 Performance, anthropometric and body composition results befor and after diet intervention

\begin{tabular}{lcccc}
\hline \multicolumn{1}{c}{$\begin{array}{c}\text { VLCKD } \\
\text { start }\end{array}$} & $\begin{array}{c}\text { VLCKD } \\
\text { end }\end{array}$ & $\begin{array}{c}\text { WD } \\
\text { start }\end{array}$ & $\begin{array}{c}\text { WD } \\
\text { end }\end{array}$ \\
\hline performance results & & & & \\
SJ & $0.42 \pm 0.04$ & $0.42 \pm 0.05$ & $0.41 \pm 0.04$ & $0.40 \pm 0.04$ \\
CMJ & $0.45 \pm 0.04$ & $0.43 \pm 0.05$ & $0.43 \pm 0.06$ & $0.43 \pm 0.05$ \\
reverse grip chins & $17 \pm 4.2$ & $16.6 \pm 4.6$ & $15.2 \pm 3.4$ & $15.2 \pm 5.8$ \\
push-ups & $36 \pm 6.3$ & $38.8 \pm 4.7$ & $37 \pm 11.8$ & $43.5 \pm 18.1$ \\
legs closed barrier & $19.2 \pm 4.96$ & $21.7 \pm 6.35$ & $17.2 \pm 5.0$ & $16 \pm 4.77$ \\
parallel bar dips & $25.8 \pm 8.35$ & $28.2 \pm 9.31$ & $23 \pm 12.19$ & $27 \pm 10.61$ \\
Anthropometric and body composition results & \\
muscle Kg & $37.6 \pm 3.9$ & $37.9 \pm 4.5$ & $38.4 \pm 4.1$ & $38.6 \pm 4.5$ \\
Fat Kg & $5.3 \pm 1.3$ & $3.4 \pm 0.8 * *$ & $5.1 \pm 1.3$ & $4.9 \pm 1.1$ \\
fat \% & $7.6 \pm 1.4$ & $5.0 \pm 0.9 * *$ & $8.0 \pm 1.3$ & $7.7 \pm 1.2$ \\
Lean body mass Kg & $64.2 \pm 6.5$ & $63.1 \pm 7.1$ & $61.5 \pm 4.3$ & $61.8 \pm 4.6$ \\
lean body mass \% & $92.4 \pm 1.4$ & $95.0 \pm 1.0 * *$ & $92.0 \pm 1.3$ & $92.3 \pm 1.2$ \\
Weight & $69.6 \pm 7.3$ & $68.0 \pm 7.5 * *$ & $70.1 \pm 6.2$ & $70.0 \pm 6.3$
\end{tabular}

Data are espresse as mean and SD. Symbols: ${ }^{*}=p<0.001$ significant

difference from baseline; ${ }^{*}=p<0.05$ significant difference from basline.

procedures for body weight reduction (low calorie diets, deliberate dehydration, saunas, pharmacological methods) that are in very widespread use by athletes, especially those competing in sports with weight categories, only few studies examining VLCKD and exercise have been published. Phinney [19] found that in moderately obese, untrained subjects a prolonged exercise at $60 \%$ of $\mathrm{VO}_{2}$ max can be sustained in the virtual absence of dietary carbohydrate $(<10 \mathrm{~g} / \mathrm{d})$ for 6 wk with a surprising increase in treadmill time duration of $155 \%$ respect to baseline (from 168 to 259 minutes). In a second study [57], Phinney studied the effect of chronic ketosis on exercise performance in endurance-trained athletes finding that aerobic endurance exercise by well-trained cyclists was not compromised by four weeks of ketosis. In contrast White suggested that VLCKD enhanced perception of fatigue during a 90 min walk, but in this study only
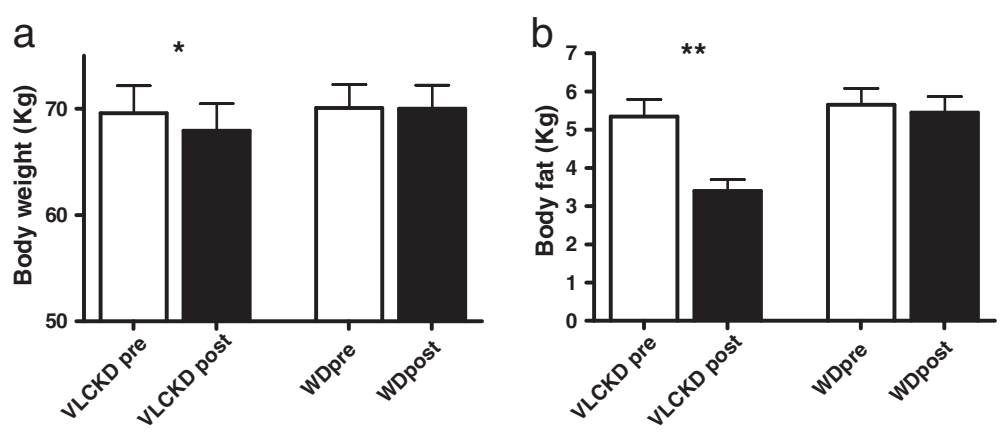

Figure $\mathbf{2}$ Changes in body weight (a) and kilograms of fat (b) before and after very low carbohydrate diet and western diet. SD are showed with bars. 
RPE (Rate of Perceived Exertion) was significant whilst average heart rate and exercise intensity expressed at \% HR max did not change. Unfortunately other performance indexes such as $\mathrm{VO}_{2} \mathrm{max}$ and blood lactate were not investigated [22]. More recently a broader study [18] reported that a ketogenic diet enhanced fat oxidation without detrimental effects on maximal or submaximal markers of aerobic exercise performance in obese subjects. Interestingly, to our knowledge, this is the first study published that measured the effects of VLCKD on strength performance and the authors reported no difference in strength isometric performance between VLCKD group and high carbohydrate group.

Three factors should be taken into account to explain these conflicting results: 1) the time needed for ketoadapatation (approximately 7 days), 2) usage or not of electrolyte supplementation 3 ) the protein intake. According to the first factor, most studies have maintained the VLCKD for less than two weeks, which not sufficient to accomplish the full ketogenic metabolic adjustment (since 7 days are required for keto-adaptation leaving just a few days to see the effects of ketosis during these short dietary protocols). In our experimental design the ketogenic period was maintained for 30 days. Regarding adequate electrolyte supplementation it is noteworthy that a supplement containing sodium and potassium is needed to maintain an effective nitrogen balance with functional tissue preservation [58] and the Tisanoreica ${ }^{\circledR}$ protocol reported here included an electrolyte supplementation [16]. Finally to maintain lean body mass a protein intake of $1.2-1.7 \mathrm{~g} / \mathrm{kg} / \mathrm{bw}$ with reference to body weight is required [58]. Most techniques used for weight loss in sports lead to a reduction of lean body mass with consequent negative effects on performance. The effects of the reduction in daily protein intake below $1.2 \mathrm{~g} /$ $\mathrm{kg} / \mathrm{bw}$ during a VLCKD, includes the gradual loss of lean tissue and therefore the loss of physical performance as demonstrated by Davis [59]. The daily intake of protein during the ketogenic phase in our study was approximately $2.8 \mathrm{~g} / \mathrm{kg}$ (assuming an increased protein requirement due to the very intense physical activity) $[60,61]$. White et. al., provided 30\% of caloric intake from protein [22] and basing calculations on a previous report by the same group [62], provided a daily intake of $125 \mathrm{~g}$, probably not enough to provide the necessary amount of amino acids for gluconeogenesis. It is known that for the preservation of muscle and an adequate level of physical performance during a restricted diet a minimum of $135 \mathrm{~g}$ of protein per day is necessary for a subject of $80 \mathrm{~kg}$. Eaton suggests that in ancestral humans, protein provided about $30 \%$ of daily energy intake (which corresponds to an intake of approximately $3 \mathrm{~g} / \mathrm{kg}$ per day for a $70 \mathrm{~kg}$ individual consuming $12500 \mathrm{~kJ}$ (3000 kcal)/d [63]. In our study, it can be observed that despite a significant decrease of fat percentage and fat absolute amount, the strength performances remained stable after
30 days of VLCKD. Recently we have summarized the factors involved in the fat loss effect of VLCKD diets [12]:

1. Satiety effect of proteins leading to appetite reduction in which also ketone bodies may have a role, although the mechanism is not clear;

2. > Reduction in lipid synthesis and increased lipolysis mechanisms;

3. Reduction in at rest respiratory quotient and therefore an increase in fat metabolism for energy use;

4. Increased metabolic expenditure caused by gluconeogenesis and the thermic effect of proteins.

The maintenance (or strictly speaking the visible increase, albeit not significant) of the amount of lean body mass, muscle and percentage of muscle during the period of VLCKD needs to be underlined and this muscle sparing effect can be explained through the mechanism of ketosis. As stated before, fatty acids which are normally used as a major fuel for some tissues such as muscle, cannot be used by the CNS because they cannot cross the blood-brain barrier. During starvation (fasting) this becomes a problem, particularly for organisms such as humans in which CNS metabolism constitutes a major portion of the resting basal metabolic rate $(\sim 20 \%)$. During the initial fasting period our body provides glucose for the metabolic needs of the CNS via break down of muscle tissue to provide the amino acid precursors for gluconeogenesis. Obviously the organism could not survive long under such wasting conditions and ketone bodies (KB) therefore represent an alternate fatbased fuel source that spares muscle protein [12]. It is noteworthy that the mechanism underlying the increase of body fat utilization has some pathways in common with mechanisms contributing to the lack of muscle mass increase. The use of FFA and ketones for muscle fuel spares muscle protein and is thus anti-catabolic. During the ketogenic period, whilst blood glucose decreases by a small amount, remaining at around $80-90 \mathrm{mg} / \mathrm{dl}$, insulin remains at very low levels $(7 \mathrm{mU} / \mathrm{L})[58,64,65]$. Insulin is involved in increased liposynthesis and decreased lipolysis so a reduction in insulin levels facilitates mobilization from fat stores; on the other hand insulin is fundamental for the muscle growth pathway (via IGF-1, mTOR, AKT etc.). Our data confirm that during the ketogenic diet it is actually very difficult to increase muscle mass and therefore the maintenance of muscle mass, the lack of lean mass loss, may be considered a successful objective for our athletes. We noted that some athletes complained that they were not able to finish the exercises proposed during the training but these were temporary effects present only during the first week after which they disappeared completely. One of the limits of our research is the low sample number due to the common problem of recruiting high level athletes for experimental protocol during the competitive season. It is 
possible to conclude though that physical performance was not altered in these well-trained individuals using an isocaloric low-CHO diet $\left(<20 \mathrm{~g} \cdot \mathrm{d}^{-1} \mathrm{CHO}\right)$ with an adequate vitamin, minerals and protein $\left(2.8 \mathrm{~g} \cdot \mathrm{kg}^{-1} \cdot \mathrm{d}^{-1}\right)$ supply, compared to a normal diet.

\section{Conclusions}

Many coaches do not favorably accept the use of a ketogenic diet by their athletes, both due to the absence of knowledge of the effects of the LCKD and due to fear that the diet can rebound on the physical performance of the athlete. Unfortunately there are very few studies on the topic "ketogenic diet and exercise", showing consistent methods and results. Those that reported negative effects of VLCKD on performance were only carried out for a time of up to 15 days [22]; but a longer period of time is necessary in order to induce the keto-adaptation [66]. This process of keto-adaptation seems to require a significant adherence to the dietary restriction of carbohydrate that needs to last at least 10/14 days to produce the positive reported effects. Individuals who intermittently consume carbohydrates during a ketogenic diet reduce their tolerance to exercise $[18,19,22,58]$. Our data suggest that athletes who underwent a VLCKD with adequate protein intake lost weight and improved body composition without any negative changes in strength and power performance. Taken together these results suggest that a properly monitored and programmed ketogenic diet could be a useful, and safe, method to allow the athletes to reach their desired weight categories without the unnecessary and harmful procedures currently in use. In conclusion, this dietetic approach in the short term could be helpful in sports that involve weight categories.

\section{Competing interests}

This work was partially funded by GianlucaMechSpA, Orgiano (VI), Italy. GianlucaMechSpA AP and LC research activity is funded by dept. of Human Anatomy and Physiology, University of Padova; KG research activity is funded by the Biomedical Engineering Laboratory, Institute of Communication and Computer Systems, National Technical University of Athens, Athens, Greece. AP has been a consultant for and has received grant/research support from Gianluca Mech Spa. LC is scientific consultant for Gianluca Mech SpA,

Asigliano Veneto (VI), Italy. The other authors declare no competing interests. Investigators conducted the study in its entirety and maintained exclusive control of all data and analyses. The funding source had no involvement in any part of the recruitment of participants, study intervention, data collection, data analyses, interpretation of the data, or preparation or review of this manuscript.

\section{Authors' contributions}

A Paoli was the main researcher and was responsible for study design, statistical analysis and interpretation of data and draft of manuscript, conceived the study, participated in its design, drafted the manuscript and performed the statistical analysis. KG was responsible for analysis and interpretation of data and helped to draft the manuscript. D D'A participated in the study design and coordination and helped to draft the manuscript. CB was responsible for study design and acquisition of data. LC was responsible for diet prescription and analysis. TM helped to draft the manuscript. AB participated in the design of the study and in the statistical analysis. A Palma participated in the design of the study and helped to draft the manuscript. All authors read and approved the final manuscript.

\section{Author details}

'Physiological Laboratory - Department of Biomedical Sciences, University of Padova, Padova, Italy. ${ }^{2}$ Human Movement Sciences School, University of Padova, Padova, Italy. ${ }^{3}$ Biomedical Engineering Laboratory, Institute of Communication and Computer Systems, National Technical University of Athens, Athens, Greece. ${ }^{4}$ Department of Molecular Pharmacology \& Physiology College of Medicine, University of South Florida, Tampa, FL, USA. ${ }^{5}$ Tisanoreica Study Center, Lonigo, Vicenza, Italy. ${ }^{6}$ Department of Sports and Exercise Science (DISMOT), University of Palermo, Palermo, Italy.

Received: 8 March 2012 Accepted: 26 July 2012

Published: 26 July 2012

\section{References}

1. Turocy PS, DePalma BF, Horswill CA, Laquale KM, Martin TJ, Perry AC, Somova MJ, Utter AC, National Athletic Trainers' Association: National Athletic Trainers' Association position statement: safe weight loss and maintenance practices in sport and exercise. J Athl Train 2011, 46:322-336.

2. Oppliger RA, Steen SA, Scott JR: Weight loss practices of college wrestlers. Int J Sport Nutr Exerc Metab 2003, 13:29-46.

3. Cadwallader AB, de la Torre X, Tieri A, Botre F: The abuse of diuretics as performance-enhancing drugs and masking agents in sport doping: pharmacology, toxicology and analysis. Br J Pharmacol 2010, 161:1-16.

4. Oppliger RA, Case HS, Horswill CA, Landry GL, Shelter AC: American College of Sports Medicine position stand. Weight loss in wrestlers. Med Sci Sports Exerc 1996, 28:ix-xii.

5. Yarrows SA: Weight loss through dehydration in amateur wrestling. J Am Diet Assoc 1988, 88:491-493.

6. Caldwell JE, Ahonen E, Nousiainen U: Differential effects of sauna-, diuretic-, and exercise-induced hypohydration. J Appl Physiol 1984 57:1018-1023

7. Shephard RJ: Electrolyte manipulation in female body-builders. Br I Sports Med 1994, 28:60-61.

8. Krilanovich NJ: Benefits of ketogenic diets. Am J Clin Nutr 2007, 85:238-239. author reply 239-40.

9. Cahill GF Jr: Fuel metabolism in starvation. Annu Rev Nutr 2006, 26:1-22.

10. Pethick DW, Lindsay DB: Metabolism of ketone bodies in pregnant sheep. Br J Nutr 1982, 48:549-563.

11. Krebs HA: The regulation of the release of ketone bodies by the liver. Adv Enzym Regul 1966, 4:339-354.

12. Paoli A, Canato M, Toniolo L, Bargossi AM, Neri M, Mediati M, Alesso D, Sanna G, Grimaldi KA, Fazzari AL, Bianco A: The ketogenic diet: an underappreciated therapeutic option? Clin Ter 2011, 162:e145-e153.

13. Gardner CD: Low-carbohydrate ketogenic diet and the combination of orlistat with a low-fat diet lead to comparable improvements in weight and blood lipids, but LCKD more beneficial for blood pressure. Evid Based Med 2010, 15.91-92.

14. Gardner CD, Kiazand A, Alhassan S, Kim S, Stafford RS, Balise RR, Kraemer HC, King AC: Comparison of the Atkins, Zone, Ornish, and LEARN diets for change in weight and related risk factors among overweight premenopausal women: the A TO Z Weight Loss Study: a randomized trial. JAMA 2007. 297:969-977.

15. Shai I, Schwarzfuchs D, Henkin Y, Shahar DR, Witkow S, Greenberg I, Golan R, Fraser D, Bolotin A, Vardi H, Tangi-Rozental O, Zuk-Ramot R, Sarusi B, Brickner D, Schwartz Z, Sheiner E, Marko R, Katorza E, Thiery J, Fiedler GM, Bluher M, Stumvoll M, Stampfer MJ, Dietary Intervention Randomized Controlled Trial (DIRECT) Group: Weight loss with a low-carbohydrate, Mediterranean, or low-fat diet. N Engl J Med 2008 359:229-241

16. Paoli A, Cenci L, Grimaldi KA: Effect of Ketogenic Mediterranean diet with phytoextracts and low carbohydrates/high-protein meals on weight, cardiovascular risk factors, body composition and diet compliance in Italian council employees. Nutr J 2011, 10:112.

17. Kreider RB, Rasmussen C, Kerksick CM, Wilborn C, Taylor $L$ 4th, Campbell B, Magrans-Courtney T, Fogt D, Ferreira M, Li R, Galbreath M, losia M, Cooke M, Serra M, Gutierrez J, Byrd M, Kresta JY, Simbo S, Oliver J, Greenwood M: A carbohydrate-restricted diet during resistance training promotes more favorable changes in body composition and markers of health in obese women with and without insulin resistance. Phys Sportsmed 2011, 39:27-40. 
18. Brinkworth GD, Noakes M, Clifton PM, Buckley JD: Effects of a low carbohydrate weight loss diet on exercise capacity and tolerance in obese subjects. Obesity (Silver Spring) 2009, 17:1916-1923.

19. Phinney SD, Horton ES, Sims EA, Hanson JS, Danforth E Jr, LaGrange BM: Capacity for moderate exercise in obese subjects after adaptation to a hypocaloric, ketogenic diet. J Clin Invest 1980, 66:1152-1161.

20. Walberg JL, Ruiz VK, Tarlton SL, Hinkle DE, Thye FW: Exercise capacity and nitrogen loss during a high or low carbohydrate diet. Med Sci Sports Exerc 1988, 20:34-43.

21. Russell DM, Leiter LA, Whitwell J, Marliss EB, Jeejeebhoy KN: Skeletal muscle function during hypocaloric diets and fasting: a comparison with standard nutritional assessment parameters. Am J Clin Nutr 1983, 37:133-138.

22. White AM, Johnston CS, Swan PD, Tjonn SL, Sears B: Blood ketones are directly related to fatigue and perceived effort during exercise in overweight adults adhering to low-carbohydrate diets for weight loss: a pilot study. J Am Diet Assoc 2007, 107:1792-1796.

23. Bogardus C, LaGrange BM, Horton ES, Sims EA: Comparison of carbohydrate-containing and carbohydrate-restricted hypocaloric diets in the treatment of obesity. Endurance and metabolic fuel homeostasis during strenuous exercise. J Clin Invest 1981, 68:399-404.

24. Paoli A, Cenci L, Fancelli M, Parmagnani A, Fratter A, Cucchi A, Bianco A: Ketogenic diet and phytoextracts Comparison of the efficacy of Mediterranean, zone and tisanoreica diet on some health risk factors. Agro Food Ind Hi-Tech 2010, 21:24-+

25. Gaby AR: Natural approaches to epilepsy. Altern Med Rev 2007, 12:9-24.

26. Zupec-Kania B, Zupanc ML: Long-term management of the ketogenic diet: seizure monitoring, nutrition, and supplementation. Epilepsia 2008, 49(Suppl 8):23-26.

27. Lugasi A, Blazovics A, Hagymasi K, Kocsis I, Kery A: Antioxidant effect of squeezed juice from black radish (Raphanus sativus $\mathrm{L}$. var niger) in alimentary hyperlipidaemia in rats. Phytother Res 2005, 19:587-591.

28. Lou Z, Wang H, Li J, Chen S, Zhu S, Ma C, Wang Z: Antioxidant activity and chemical composition of the fractions from burdock leaves. J Food Sci 2010, 75:C413-C419.

29. Di Silverio F, D'Eramo G, Lubrano C, Flammia GP, Sciarra A, Palma E, Caponera M, Sciarra F: Evidence that Serenoa repens extract displays an antiestrogenic activity in prostatic tissue of benign prostatic hypertrophy patients. Eur Urol 1992, 21:309-314.

30. Barrett ML, Udani JK: A proprietary alpha-amylase inhibitor from white bean (Phaseolus vulgaris): a review of clinical studies on weight loss and glycemic control. Nutr J 2011, 10:24.

31. Celleno L, Tolaini MV, D'Amore A, Perricone NV, Preuss HG: A Dietary supplement containing standardized Phaseolus vulgaris extract influences body composition of overweight men and women. Int J Med Sci 2007, 4:45-52.

32. Mimica-Dukic N, Simin N, Cvejic J, Jovin E, Orcic D, Bozin B: Phenolic compounds in field horsetail (Equisetum arvense L.) as natural antioxidants. Molecules 2008, 13:1455-1464.

33. Safiyeh S, Fathallah FB, Vahid N, Hossine N, Habib SS: Antidiabetic effect of Equisetum arvense L. (Equisetaceae) in streptozotocin-induced diabetes in male rats. Pak J Biol Sci 2007, 10:1661-1666.

34. Clare BA, Conroy RS, Spelman K: The diuretic effect in human subjects of an extract of Taraxacum officinale folium over a single day. J Altern Complement Med 2009, 15:929-934.

35. Pieralisi G, Ripari P, Vecchiet L: Effects of a standardized ginseng extract combined with dimethylaminoethanol bitartrate, vitamins, minerals, and trace elements on physical performance during exercise. Clin Ther 1991, 13:373-382.

36. Piato AL, Detanico BC, Linck VM, Herrmann AP, Nunes DS, Elisabetsky E: Anti-stress effects of the "tonic"Ptychopetalum olacoides (Marapuama) in mice. Phytomedicine 2010, 17:248-253.

37. Lima WP, Carnevali LC Jr, Eder R, Costa Rosa LF, Bacchi EM, Seelaender MC: Lipid metabolism in trained rats: effect of guarana (Paullinia cupana Mart.) supplementation. Clin Nutr 2005, 24:1019-1028.

38. Cordain L, Eaton SB, Sebastian A, Mann N, Lindeberg S, Watkins BA, O'Keefe $\mathrm{JH}$, Brand-Miller J: Origins and evolution of the Western diet: health implications for the 21st century. Am J Clin Nutr 2005, 81:341-354.

39. Toeller M, Buyken A, Heitkamp G, Milne R, Klischan A, Gries FA: Repeatability of three-day dietary records in the EURODIAB IDDM Complications Study. Eur J Clin Nutr 1997, 51:74-80.
40. Black KE, Skidmore PM, Brown RC: Energy intakes of ultraendurance cyclists during competition, an observational study. Int I Sport Nutr Exerc Metab 2012, 22:19-23.

41. Hume $P$, Marfell-Jones M: The importance of accurate site location for skinfold measurement. J Sports Sci 2008, 26:1333-1340.

42. Eston RG, Rowlands AV, Charlesworth S, Davies A, Hoppitt T: Prediction of DXA-determined whole body fat from skinfolds: importance of including skinfolds from the thigh and calf in young, healthy men and women. Eur J Clin Nutr 2005, 59:695-702.

43. Oppliger RA, Nielsen DH, Shetler AC, Crowley ET, Albright JP: Body composition of collegiate football players: bioelectrical impedance and skinfolds compared to hydrostatic weighing. J Orthop Sports Phys Ther 1992, 15:187-192

44. Paoli A, Pacelli F, Bargossi AM, Marcolin G, Guzzinati S, Neri M, Bianco A, Palma A: Effects of three distinct protocols of fitness training on body composition, strength and blood lactate. J Sports Med Phys Fitness 2010, 50:43-51.

45. Lohman TG, Roche AF, Martorell R: Anthropometric standardization reference manual. Champaign: Human Kinetics Books; 1991.

46. Heyward V: ASEP methods recommendation: body composition assessment. J Exerc Physiol 2001, 4:1-12

47. Asmussen $\mathrm{E}$, Bonde-Petersen F: Storage of elastic energy in skeletal muscles in man. Acta Physiol Scand 1974, 91:385-392.

48. Bosco C, Luhtanen P, Komi PV: A simple method for measurement of mechanical power in jumping. Eur J Appl Physiol Occup Physiol 1983, 50:273-282.

49. Malatesta D, Cattaneo F, Dugnani S, Maffiuletti NA: Effects of electromyostimulation training and volleyball practice on jumping ability. J Strength Cond Res 2003, 17:573-579.

50. Negrete RJ, Hanney WJ, Kolber MJ, Davies GJ, Ansley MK, McBride AB, Overstreet AL: Reliability, minimal detectable change, and normative values for tests of upper extremity function and power. J Strength Cond Res 2010, 24:3318-3325.

51. Ortega FB, Artero EG, Ruiz JR, Vicente-Rodriguez G, Bergman $P$, Hagstromer M, Ottevaere C, Nagy E, Konsta O, Rey-Lopez JP, Polito A, Dietrich S, Plada M, Beghin L, Manios Y, Sjostrom M, Castillo MJ, HELENA Study Group: Reliability of health-related physical fitness tests in European adolescents. The HELENA Study. Int J Obes (Lond) 2008, 32(Suppl 5):S49-S57.

52. Markovic G, Dizdar D, Jukic I, Cardinale M: Reliability and factorial validity of squat and countermovement jump tests. J Strength Cond Res 2004, 18:551-555.

53. Slinde F, Suber C, Suber L, Edwen CE, Svantesson U: Test-retest reliability of three different countermovement jumping tests. J Strength Cond Res 2008, 22:640-644.

54. Mayhew JL, Brechue WF, Smith AE, Kemmler W, Lauber D, Koch AJ: Impact of testing strategy on expression of upper-body work capacity and one-repetition maximum prediction after resistance training in college-aged men and women. J Strength Cond Res 2011, 25:2796-2807.

55. Brechue WF, Mayhew JL: Upper-body work capacity and 1RM prediction are unaltered by increasing muscular strength in college football players. J Strength Cond Res 2009, 23:2477-2486.

56. Adam-Perrot A, Clifton P, Brouns F: Low-carbohydrate diets: nutritional and physiological aspects. Obes Rev 2006, 7:49-58.

57. Phinney SD, Bistrian BR, Evans WJ, Gervino E, Blackburn GL: The human metabolic response to chronic ketosis without caloric restriction: preservation of submaximal exercise capability with reduced carbohydrate oxidation. Metabolism 1983, 32:769-776.

58. Phinney SD: Ketogenic diets and physical performance. Nutr Metab (Lond) 2004, 1:2.

59. Davis PG, Phinney SD: Differential effects of two very low calorie diets on aerobic and anaerobic performance. Int J Obes 1990, 14:779-787.

60. Lemon PW: Do athletes need more dietary protein and amino acids? Int J Sport Nutr 1995, 5(Suppl):S39-S61.

61. Lemon PW, Tarnopolsky MA, MacDougall JD, Atkinson SA: Protein requirements and muscle mass/strength changes during intensive training in novice bodybuilders. J Appl Physiol 1992, 73:767-775.

62. Johnston CS, Tjonn SL, Swan PD, White A, Hutchins H, Sears B: Ketogenic low-carbohydrate diets have no metabolic advantage over nonketogenic low-carbohydrate diets. Am J Clin Nutr 2006, 83:1055-1061.

63. Eaton SB, Cordain L, Sparling PB: Evolution, body composition, insulin receptor competition, and insulin resistance. Prev Med 2009, 49:283-285. 
64. Phinney SD, Bistrian BR, Wolfe RR, Blackburn GL: The human metabolic response to chronic ketosis without caloric restriction: physical and biochemical adaptation. Metabolism 1983, 32:757-768

65. Noakes M, Foster PR, Keogh JB, James AP, Mamo JC, Clifton PM: Comparison of isocaloric very low carbohydrate/high saturated fat and high carbohydrate/low saturated fat diets on body composition and cardiovascular risk. Nutr Metab (Lond) 2006, 3:7.

66. McClernon FJ, Yancy WS Jr, Eberstein JA, Atkins RC, Westman EC: The effects of a low-carbohydrate ketogenic diet and a low-fat diet on mood, hunger, and other self-reported symptoms. Obesity (Silver Spring) 2007, 15:182-187.

doi:10.1186/1550-2783-9-34

Cite this article as: Paoli et al:: Ketogenic diet does not affect strength performance in elite artistic gymnasts. Journal of the International Society of Sports Nutrition 2012 9:34.

\section{Submit your next manuscript to BioMed Central and take full advantage of:}

- Convenient online submission

- Thorough peer review

- No space constraints or color figure charges

- Immediate publication on acceptance

- Inclusion in PubMed, CAS, Scopus and Google Scholar

- Research which is freely available for redistribution 